\title{
Privatization: A Solution to Problems of Public Enterprises
}

\author{
MOHAMMED FATTHY MAHMOUD \\ Professor \\ Department of Public Administration \\ College of Administrative Sciences \\ King Saud University, Riyadh, Saudi Arabia
}

\begin{abstract}
Most countries, despite differences in their levels of development, political tendencies, and economic systems, are turning towards privatization. This involves the devolution of government property and assets, involving certain governmental services and responsibilities, to the private sector. Practical application of this concept has, in turn, brought forth solutions to some of the fundamental problems of the public sector.

The aim of this paper is to evaluate privatization as a method of overcoming the problems facing public enterprises. It examines the factors contributing to the poor performance of public enterprises and outlines the objectives of privatization.

The paper draws on the privatization experience of various countries and discusses the obstacles to privatization and the effect of competition on privatized firms. 'The requirements for a successful privatization programme are also outlined.
\end{abstract}

\section{Introduction}

State-owned enterprises exist in all countries: developing and developed, market and socialist. They produce a broad range of goods and services such as power, communications, steel, fertilizers, automobiles and petrochemicals. The performance of these public enterprises varies widely within and between countries, but their record has frequently been poor, particularly in developing countries. They have clearly failed to play the strategic role in industrialization that governments had hoped for.

To improve efficiency and competition, governments in industrial and developing countries alike are divesting their ownership of public enterprises through liquidation which involves the closure of the enterprise, or the suspension of some or all of its operations, privatization of management using leases and management contracts, or privatization of ownership through the sale of assets to the private sector. ${ }^{(1)}$

(1) E. S. Savn, Privatization in Post-Socialist Countries, Public Administration Review, November/December 1992, Vol. 52, No. 6, pp. 573-574 
This paper is concerned only with the third course of action, ie., privatization of ownership. The study is divided into six sections. Section one discusses briefly the general problems facing state-owned enterprises. Section two outlines the objectives of privatization and refers to the experience of various countries. The effects of competition on privatization are considered in section three, while section four examines the obstacles, to privatization. Section five, outlines the requirements for a successful privatization programme based on the experience of countries which followed this course of action. Finally, section six summarizes the main conclusions of the study.

\section{1- Problems of Performance of State-owned Enterprises}

State-owned enterprises (SOEs) comprise a large and rapidly growing sector of the economy in the majority of countries in the world today. They have been created for a variety of reasons. These include:

(1) Spearheading industrialization in countries with virtually no large-scale industry.

(2) Promotion of industries deemed to be of strategic importance.

(3) Creating lines of activities with no sufficient incentive for private investment.

(4) Establishing projects which require huge amounts of capital, not easy to raise privately within the present structure of the capital markets.

(5) Saving of threatened jobs.

(6) Reducing the presence or preventing the entry of foreign-owned firms.

(7) Expanding the public sector.

(8) Raising more revenue for the government to finance development, capital expenditure, or current expenditure.

(9) Avoiding the evils of private monopoly over strategic industries.

(10) Securing the sale of goods and services at reasonably low prices, particularly for the poorer customers.

(11) Other social or political reasons. ${ }^{(2)}$

The performance of the state-owned enterprises has, in General, been poor. In particular:

(1) Financial rates of return have generally been lower for public enterprises than for the private sector. ${ }^{(3)}$

(2) Financial profitability has been. compromised by price controls. ${ }^{(4)}$.

(3) Public enterprises have often put large burdens on public budgets.

(2) Yari Aharoni, State-owned enterprises: An Agent Without a Principal, in L. P. Jones (ed.), Public Enterprise in Less Developed Countries, Cambridge: Cambridge University Press, 1982, pp. 67-76.

(3) Emilio Sacistan Ray, Some Consideration on the Role of Public Enterprise, in W. J. Baumol (ed.), Public and Private Enterprise in a Mixed Economy, London: The Macmillan Press Ltd., 1980, pp.44-52.

(4) World Bank, World Development Report, Oxford, Oxford University Press, 1983, pp. 74-79. 
(4) State-owned enterprises contributed to the augmentation of the external debt of many developing countries.

(5) Countries in which public enterprises accounted for higher shares of gross domestic investment generally had lower rates of economic growth.

A number of reasons account for the poor performance of public enterprises. These include:

\section{(1) Lack of Incentives on the Part of Management}

Few countries have used performance bonuses or profit sharing to motivate top management. Also, in some countries, managers are part of the civil service or at least subject to its pay scale. Even where this is not the case, their pay seldom matches private salaries. Although the prestige and challenge of running what are often the largest corporations in the country may sometimes compensate for lower pay, low salaries tend to deter skilled managers and increase staff turnover. ${ }^{(5)}$

\section{(2) Shortage of Competent Managers}

The growing number of public enterprises in many Sub-Saharan African and other countries, has contributed to a chronic shortage of management. This shortage has been sometimes, exacerbated by programme, for rapid indigenization. ${ }^{(6)}$ Many senior posts are left vacant or are filled by unqualified staff. The organization thus becomes too dependent on its chief executive. The shortage of managers also contributes to a high rate of turnover as competent people are shifted around to head troubled government enterprises. Even countries without a managerial shortage change the managers of the state-owned enterprises with damaging frequency if selection of top managers is based on nepotism or political patronage.

\section{(3) Lack of Competition}

Many state-owned firms are monopolies producing goods and services that are not traded internationally or that the government prefers to produce domestically for reasons of national security or public interest. In other cases the economy may be too small to support another domestic producer. Also, managers are Rot given discretion to respond to competitive pressures which may mean reducing staff or ending unprofitable service.

\section{(4) Little Emphasis on Profitability and Efficiency}

The public enterprises are not instructed to maximize profits or even to minimize costs since adjusting administered prices typically involves practical and political problems.

\section{(5) Conflicting Goals}

The state-owned enterprises are often required to perform noncommercial roles such as hiring extra staff to increase employment or setting up a plant in a particular area to promote regional development or entering into a completely different line of activity to achieve diversification. These conflicting goals often reduce profits.

(5) Mahmood A. Ayub and Seven O. Hegsted, Management of Public Industrial Enterprises, World Bank Research Observer, January 1987, Vol. 2, No. 1, pp. 79-101.

(6) J. R. Nellis, Public Enterprises in Sub-Saharan Africa, World Bank, Discussion Paper 1, Washington D.C., 1986 


\section{(6) Lack of Effective Accountability}

Only a few countries apply organized public pressure as a way of increasing the efficiency of public enterprises. ${ }^{(7)}$ Also, governments seldom take action to remove inefficient managers of these enterprises. Moreover, governments are rarely prepared to use the sanction of liquidation.

\section{(7) Government Intervention}

All too often, different agencies intervene instate-owned enterprises decisions that should be the prerogative of management, and yet management fails to coordinate their action. Too much interference can be combined with too little control. In addition, policy that swings between autonomy and central control can prevent coherent direction of public enterprises. Many attempts to reduce arbitrary intervention by government have become counterproductive, substituting one form of ex-ante bureaucratic intervention for another. ${ }^{(8)}$

\section{(8) Absence of Reliable Information on Performance}

In many developing countries the internal management information Systems of public enterprises are deficient or non-existent. The companies are not audited according to uniform standards. This is due to lack of a trained body practitioners and qualified accountants as well as lack of active plans designed to focus efforts on improving efficiency and monitoring results.

Public enterprises are frequently expected to contribute to the broader goals of government policy. The consequences can be perverse. For instance, public enterprises' prices may be controlled to benefit the poor or to assist counterinflationary policies. But these firms' consumers are often large industrial users or wealthy people, so they-not the poor-benefit most. It is estimated that three-quarters of the energy and food subsidies in Egypt went to the relatively more affluent urban areas and about two-thirds of these went to the richer half of the urban population. ${ }^{(9)}$

There is what we call "a circular flow of effects of inefficiency of state-owned enterprises". This is demonstrated in Fig. (1). The chart shows that the gains to the poor in terms of low prices are paid for by the poor themselves either directly through taxation or indirectly through inflation. This is because the costs of subsidies are shifted from the consumer to the taxpayer or, if the deficit is financed through inflationary monetary expansion, to the public at large. Given the regressive nature of taxes in many developing countries and the impact of inflation on the poor, the net result may be a worsening position of the poor and an increase in income inequalities.

(7) R. Vernon and Yari Aharoni (eds.), State-owned Enterprises in the Western Economics, New York: St. Martin's, 1981.

(8) World Bank, World Development Report 1991: The Challenge of Development, Oxford: Oxford University Press, 1991, p. 102.

(9) World Bank, World Development Report, Oxford: Oxford University Press, 1983, pp. 74-79. 


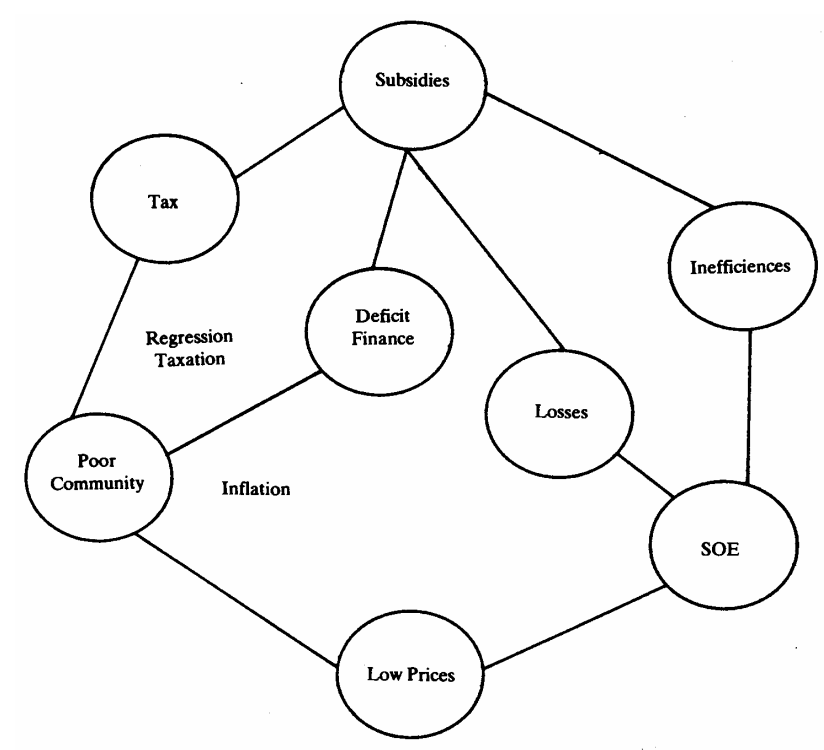

Fig., (1). The circular flow of inefficiency of state-owned enterprises (SOES).

\section{Objectives of Privatization}

The main objectives of privatization may be summarized in the following:

(1) The reduction of the state sector.

(2) Promotion of wide share ownership

(3) Greater efficiency within privatized entities, coupled with profit motivated decisions.

(4) Raising revenue for the government.

(5) Reduced government interference, increasing speed of decision making.

(6) Introduction or enhancement of competition.

(7) Exposure to the disciplines and opportunities of private sector markets for capital and other resources.

The above objectives need not be equally important for all state-owned enterprises. Also, these goals are not mutually exclusive ${ }^{(10)}$ Obviously, the government in each country will need to consider local factors and individual industry circumstances in determining the mix of goals.

The UK government has been recognized as pioneering in privatization practice. However, many developed and developing countries emulate British privatization, albeit adapting to alternative approaches. These countries include France, Italy, Portugal, Spain, Holland, Denmark, Finland, West Germany, Austria, Turkey, Egypt, USA, Canada, Mexico, Jamaica, Chile, Brazil, Japan, Malaysia, New Zealand, Kenya and South Africa ${ }^{(11)}$ Generally, however, the number and importance of the enterprises

(10) J. A. Kay, C. P. Mayer and D. J. Thompson, Privatization and Regulation: The UK Experience, Oxford: Oxford University Press, 1986.

(11) J. A. Kay and D. J. Thompson, Privatisation: A Policy in Search of Rationale, The Economic Journal, Vol. 96, June 1986, pp.18-32. 
sold in developing countries is not large. But the process is moving at a fast pace. For example, Brazil created a commission for diverstiture in 1981; by mid-1982 it had sold ten enterprises and was in the process of selling another thirty six. Jamaica has set up a divestiture committee which has sold three enterprises and leased four hotels. Pakistan denationalized some 200 rice, flour and cotton mills, while Bangladesh returned 35 jute and 23 textile mills to the private sector ${ }^{(12)}$. The appendix gives information on various countries experiences with privatization.

The efficiency gains from privatization are:

(1) To establish a set of prices which more closely match costs.

(2) To use technology which minimizes economic costs as opposed to employee welfare.

(3) To set a level of output which more closely matches marginal costs with marginal benefits.

(4) To reduce the cost of inefficiencies which lead to a greater need for subsidization in the current institutional framework ${ }^{(13)}$.

3. Privatization and Competition.

In owner-managed private firms, the owner-manager has an incentive to maximize the present value of his assets and generally to reduce the cost of production. In large private firms, managers will normally be employed by the owners (shareholders) and this separation of ownership from management may reduce pressures on management to run the firm efficiently. So long as his individual share in profits remain small, any one owner will not have a great incentive to force managers to operate the firm efficiently ${ }^{(14)}$. However, competition between managers and more particularly transferability of ownership, will limit the divergence between the aims of managers and shoreholders. Transferable property rights will encourage the pursuit of profits and hence the search for ways of reducing costs or producing more valued outputs. By contrast, the absence of explicit claimants to returns to capital in publicly-owned firms produces a bias in such firms towards an overexpansion of output and a general undervaluation of capital inputs ${ }^{(15)}$.

However, privatization alone is not sufficient to deliver the benefits of a market system. The other crucial ingredient is competition. While private ownership provides an incentive to maximize profit, and hence reduce cost, without competition the private firms will be able to charge a price in excess of marginal cost. This will result in an efficient level of output. The cost of society to increase output of the commodity in question would fall short of the benefits to consumers from doing so.

The argument is illustrated in Fig. (2): DD represents the demand curve facing the firm while MR represents the firms marginal revenue and MC its marginal cost.

(12) Leroy P. Jones and Lawrence H. Wortzel, Public Enterprises and Manufactured Exports in Less developed Countries: Institutional and Market Factors Determining Comparative Advantages, in Lory P. Jones (ed.), Public Enterprise in Less Developed Countries, Cambridge: Cambridge University Press, 1982, pp. 217-239.

(13) M. R. Bishop and J. A. Kay, The Impact of Privatization on the Performance of the UK Public Sector, A paper presented at the The 15th Annual Conference of Earie, Rotterdam, 1988.

(14) W. j. Baumol, John C. Panzar and Robert D. Willing, Contestable Markets and the Theory of Industry Structure, New York: Harcourt Brace Jovanovich Inc., 1982, pp. 121-122 \& 331-332.

(15) R, Pryke, The Competitive Performance of Public and Private Enterprise, Fiscal Studies, Vol. 3, No. 2, 1982, pp.12-29. 
Equilibrium takes place at the point where $\mathrm{MR}=\mathrm{MC}$, i.e., at an output level of $\mathrm{OQ}$ and a price of OP. Efficient output, however, is determined at the point where the marginal cost curve intersects the demand curve, i.e., an output level of $\mathrm{OQ}_{\mathrm{F}}$. This is the expected equilibrium if the market is operating at perfect competition. Thus, while a publicly owned monopoly will have a tendency to over-produce, a private-owned one would have a tendency to under-produce ${ }^{(16)}$.

The above suggests that many of the potential gains from privatization may not be captured if the public firm is turned into a private monopoly. This is a real possibility given the structure of most state-own enterprises. The technologies in some of these industries are such that even if a large number of firms start out in the industry, there will be a tendency for just one of them to become dominant-the industry characterized as being a natural monopoly. The basic requirement for an industry to be a natural monopoly is that the average costs of producing output continually decline as more output is produced. In that case, the largest firm will always have the lowest cost and thus can undercut its competitors and drive them out of business. It is argued that the economies of scale in setting up distribution networks turn many public utility industries into natural monopolies ${ }^{(17)}$.

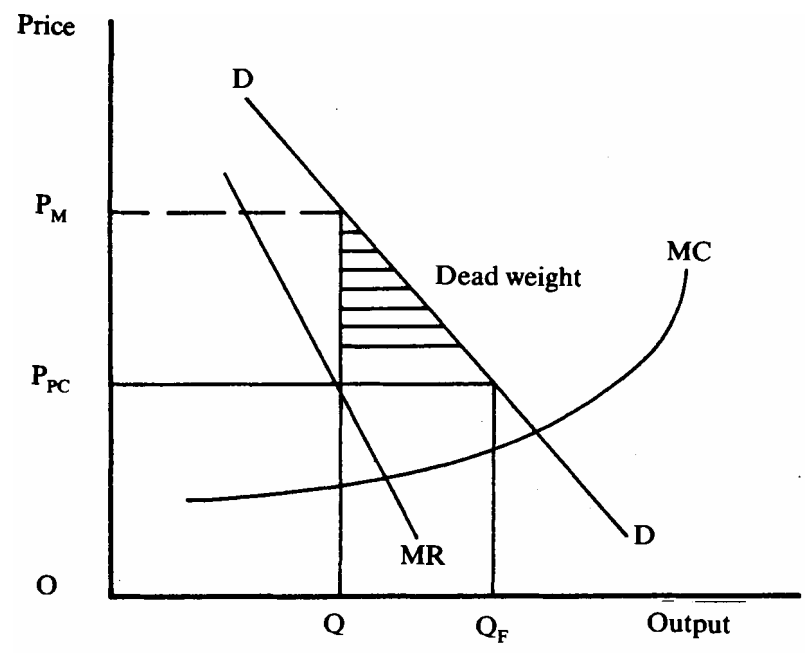

Fig. 2. Monopoly pricing and efficiency

The natural monopoly argument may provide a prima facie case for regulation of some firms. Thus, whether or not privatization leads to greater efficiency depends on the policy framework and, in particular, on the extent to which product markets are subject to competitive forces. Thus, governments should place priority on lowering entry and exit barriers and removing import barriers that restrict trade. ${ }^{(18)}$

(16) R. Millward, The Comparative Performance of Public and Private Enterprise, in Lord Roll (ed.), The Mixed Economy, London: Macmillan, 1982.

(17) P. R. Hartely, Privatization: Lessons from Public Utilities, Institute of Public Policy Research, Paper No. 4, UK, 1986.

(18) R. Rees, A Positive Theory of the Public Enterprise, in M. Marchand, P. Pestieau and H. Tulkens 


\section{(4) Obstacles to Privatization}

Although privatization can produce important net gains to society when the costs of public operation outweigh the benefits, it has been hard to implement, particularly in developing countries, for a number of reasons:

(1) Privatization is politically sensitive and prompts charges of corruption. It tends to arouse political opposition from employees who may lose their jobs, from politician who fear the short-term unemployment consequences of liquidation or of cost reduction by private owners, from bureaucrats who stand to lose patronage and from those sections of the public that fear that national assets are being concerned by the rich, a particular ethnic group or foreigners.

(2) Governments often try to sell only their money losers, for which there are few buyers. Even profitable state-owned enterprises may be hard to sell. The reasons given include fear of re-nationalization and concern about extensive government regulation of formerly public firms. ${ }^{(19)}$ These perceptions may mean governments have to accept a lower price than the market value for a similar private firm.

(3) Absence of a strong capital market. The state-owned enterprises are often big and domestic investors may not be able to raise enough capital to buy them. And selling large state-owned enterprises to oligopolists who already dominate the private sector might reduce competition. It could also result in unhealthy ties between financial institutions and industry, further reducing the flexibility of capital markets. Efforts to develop the stock market and schemes that appeal to small Savers through their pension funds could make it easier for governments to divest. Spreading owner-ship more widely and divesting only gradually can improve the chances of privatization. It may even reduce the attendant political controversy. Leasing can also be a promising route to divestiture: a private manager might be brought in to run a potentially profitable enterprise for a, share of the profits and an option to buy.

(4) It will be virtually impossible to privatize most government enterprises with out affecting adversely both the employees of the enterprise and some groups of consumers $^{(20)}$. The inefficiency of government ownership is associated both with the employees and cross-subsidization of some consumers by others. If we attempt to privatize while avoiding losses for all groups, we will probably forego many, if not all, of the efficiency gains. One way of reducing costs for the affected parties is to phase the changes in gradually. However, this also delays the gains from the change, and may give opponents of the policy more time to prevent or restrict its implementation.

(5) The way privatization is carried out could make a difference to the efficiency gains. In particular if shares in the new firms are widely distributed to consumers and former employees in an attempt to encourage them, the ownership in the new firm will be very diffuse. It will be difficult to discipline management in a widely-held firm. In consequence, the owners will place less pressure on management to maximize profits and hence reduce costs.

(eds.), The Performance of Public Enterprises, Amsterdam: North-Holland, 1984

(19) J. Vickers and G. Yarrow, Privatization: An Economic Analysis, Cambridge, Mass: MIT Press, 1988.

(20) G. Yarrow, Privatization in Theory and Practice, Economic Policy, April 1986, pp. 323-377. 


\section{Requirements for a Successful Privatization Programme}

For a privatization programme to be successful, a number of conditions must be met:

\section{(1) Public Support}

The privatization programme is likely to come under fire from various sections of the community who may challenge the principle of transferring assets out of state control (particularly in connection with monopolies and where national strategic interests are at issue) and criticize the methods and terms of individual sales. The government should embark on a vigorous debate and educational programmes focusing on the credible reasons for privatization-that is capital needs and efficiency argument while defusing the emotional and political rhetoric regarding Public ownership by offering shares widely to the public. ${ }^{(21)}$

\section{(2) Managerial Ability and Support}

The privatization programme would not succeed unless the directors of the enterprises not only support the privatization approach in principle, but are also effective in selling the investment to prospective shareholders.

Since it is often the case that public companies are run by representatives from political pressure groups (or ex-army or ex-police officers) rather than a well-balanced group of directors drawn from the variety of skill bases demanded of a typical successful company, the board of directors of these enterprises may need expanding and be of sufficient standing in order to: (a) give comfort and confidence to the in vesting public, (b) endorse the valuation and (c) provide ongoing protection to the investors of the new shareholders. In addition, the management team should be fully prepared for the changes that follow from being in the private sector particularly for those companies that are floated on the stock exchange. Management of companies being privatized would be required to devote a substantial proportion of its time and effort in preparation for privatization. This preparation encompasses:

(a) Development of improved management information techniques.

(b) Better financial monitoring and, control.

(c) Development and promotion of a new public corporate image.

(d) Generating enhanced staff motivation coupled, with better corporate awareness amongst employees.

(e) Establishment of employee share options schemes together with other performance-linked incentives.

It has to be recognized, however, that it would be within the power of state corporation management to impede progress towards privatization of their organizations, although this has not been the experience of a number of countries ${ }^{(22)}$. The management of some UK corporations have, however, been reluctant to see their corporation split up. The British Gas Corporation fought a long action to delay the sale

(21) E. P. Mayer and S. A. Meadoweroft, Selling Public Assets: Techniques and Financial Implications, Fiscal Studies, Vol. 6, No. 4, 1982, pp. 31-49.

(22) T. Jenkinson and C. P. Mayer, The Privatization Process in France and UK. A paper presented to The European Institute of Public Administration, Maastricht, 1987. 
of the Corporation's oil exploration and production interests; and the National Bus Company has been arguing with the Department of Transport over the Department's wish to split up the company into smaller, more competitive units ${ }^{(23)}$.

\section{(3) Legislative Actions}

It would normally be necessary to enact specific legislations in order to transfer the state entry into a suitable body for privatization. While the detailed terms of the legislation depend on the precise circumstances of each corporation and the nature of the government's plan for its disposal, legislation will normally cover arrangements to allow ministers to transfer state corporation assets into a company, incorporate the resulting company as a public limited company governed by government legislation and to allow shares created in the company to be sold. Special attention may also need to be given to problems of unfunded liabilities associated with full index linked employee pension schemes.

\section{(4) Selection and Preparation of Enterprises}

An essential feature of a successful public offering is that the enterprise under offer must be "perceived" to be an attractive investment to the public. As such, major privatizations are no different from other major stock market floatation's and apart from the special consideration of dealing with the government as a client, there are no fundamentally different criteria for a privatization issue; the vendor and his advisor will be obliged to follow the full requirements of securities legislation ${ }^{(24)}$. Profitability is a key criterion in an assessment of a company suitability for a stock market floatation. In circumstances where the government wishes to sell off operations which do not meet acceptable standards of profitability, it may decide to make sale by private tender or by direct negotiation.

\section{(5) Adequacy of Capital Markets}

One of the fundamental requirements for successful privatization is access to a capital market of sufficient depth and maturity to absorb the issue at hand. In general, investors demonstrate an appetite for stocks which offer liquidity, stable earnings and security. It is essential, However, that there be adequate confidence and an immediate uptrend in the stock market (following the listing) in order to successfully launch public offerings.

\section{Conclusions}

The main conclusions of this study may be summarized in the following:

1. Most public enterprises failed to play the strategic role in industrialization that governments had hoped for. These enterprises' poor performance is due to lack of incentives by their managements, extensive control exercised by governments, lack of competition as a result of protection or barriers to entry, shift of emphasis from efficiency and profitability to other non-commercial objectives, absence of reliable information on performance and lack of effective accountability.

(23) E. M. Hammond, D. R. Helm and D. J. Thompson, British Gas: Options for Privatization, Fiscal Studies, Vol. 6, No. 4, 1985. pp. 11-23.

(24) E. P. Mayer and S. A. Meadoweroft, op. cit., pp. 31-49. 
2. Public enterprises are frequently expected to contribute to the broader goals of government policy. The consequences can be perverse. This study demonstrated that there is a circular flow of effects of inefficiency of state owned enterprises. The gains to the poor in terms of low prices are more than offset by contributions of the poor themselves either through regressive taxation or inflation. This may worsen the poor position and increases income inequalities.

3. Many developed and developing countries embarked on privatization programmes as a solution to problems facing public enterprises. The appendix to this study outlines the recent experience of a number of countries.

4. The efficiency gains from privatization mainly take the form of a set of prices which more closely match marginal costs, a use of technology which minimizes economic costs as opposed to employee welfare and a level of output which more closely matches marginal costs with marginal benefits.

5. If maximum efficiency gains are to be obtained from privatization, attention must be paid to the competitiveness of the resulting market structure in addition to the ownership of the firm. Strong measures are needed to deter anti competitive behavior.

6. For the privatization programme to be successful, it must win public support. Also, management of the companies being privatized must support the programme and devote, a substantial proportion of its time and effort in preparation for privatization. Moreover, one of the fundamental requirements for successful privatization is access to a capital market of sufficient depth and maturity to absorb the issue at hand. In circumstances where the government wishes to sell off operations which do not meet acceptable standards of profitability, it may decide to make sale by private tender or direct negotiation.

\section{References}

Aharoni, Yari, State-owned Enterprises: An Agent Without Principal, in Leroy P. Jones (Ed.), Public Enterprise in Less Developed Countries, Cambridge: Cambridge University Press, 1982, pp. 67-76.

Ayub, Mahmood A. and Hegstad, Seven O., Management of Public Industrial Enterprises, World Bank Research Observor, January 1987, Vol. 2, No. 1, pp.79-101.

Baumol, W. J. (ed.), Public and Private Enterprise in a Mixed Economy, New York: St. Martin's, 1980.

Baumol, W. J., Panzar, J. C. and Willing, R. D., Contestable Markets and the Theory of Industry Structure, New York: Harcourt Brace Jovanovich Inc., 1982.

Bishop, M. R. and Kay, J. A., The Impact of Privatization on the Performance of the UK Public Sector, A paper presented at The 15th Annual Conference of EARIE, Rotterdam, 1988.

Hammond, E., M., Helm, D. R. and Thompson, D. J., British Gas: Options for Privatization, Fiscal Studies, Vol. 17, No, 4, 1985, pp.11-23.

Hartley, P. R., Privatization: Lessons from Public Utilities, Institute of Public Policy Research, Paper No. 4, London, 1986.

Jones, Leroy P. and Wortgel, Lawrence H., Public Enterprises and Manufactured Exports in Less Developed Countries: Institutional and Market Forces Determining Comparative Advantage, in Leroy P. Jones (ed.), Public Enterprise in Less Developed Countries, Cambridge: Cambridge University Press, 1982.

Jenkinson, T. and Mayer, C. P., The Privatization Process in France and the UK, A paper presented to The European Institute of Public Administration, Maastricht, 1987.

Kay, J. A. and Thompson D. J., Privatization: A Policy in Search of a Rationale, The Economic Journal, Vol. 96, June 1986, pp. 18-32. 
Kay, J. A., Mayer, C. P., and Thompson, D. J., Privatization and Regulation: The UK Experience, Oxford: Oxford University Press, $1986 .$.

Mayer, E. P. and Meadowcroft, S. A., Selling Public Assets: Techniques and Financial Implications, Fiscal Studies, Vol. 6, No. 4, 1982, pp. 31-49.

Millward, R., The Comparative Performance of Public and Private Enterprises, in Led Roll (ed.), The Mixed Economy, Macmillan, London, 1982.

Nellis,, J. R., Public Enterprises in Sub-Saharan Africa, World Bank, Discussion Paper 1, Washington, D.C., 1986.

Pryke, R., The Competitive Performance of Public and Private Enterprise, Fiscal Studies, Vol. 3, No. 2, 1982, pp.12-29.

Rees, R., A Positive Theory of Public Enterprise, in M. Marchand, P. Pestieau and H. Tulkens (eds.), The Performance of Public Enterprises, Amsterdam: North Holland, 1984.

Savas, E. S.; Privatization in Post-Socialist Countries, Public Administration Review, American Society for Public Administration "ASPA", Washington, D. C., November/December 1992, Vol. 52, No. 6, pp. 573-581.

Short, P., Appraising the Role of Public Enterprises: An International Comparison, IMF Occasional Paper Series, Washington, D. C., 1983.

Vernon, R. and Aharoni, Y. (eds.), State-owned Enterprises in the Western Economics, New York: St. Martin's, 1981.

Vickers, J. and Yarrow, G., Privatization: An Economic Analysis, Cambridge-Mass.: MIT Press, 1988.

World Bask, World Development Report, Oxford University Press, 1983, 1987 and 1991.

Yarrow, G., Privatization in Theory and Practice, Economic Policy, April 1986, pp. 323-377.

Zin, Razali Mat, Administrative Processing Preparing for Privatization: Lessons for Malaysia, Public Administrative Review, National Institute of Public Administration, Lahore, Pakistan, July-December 1989, Vol. xxvii, No. 2, pp. 23-37. 


\section{Appendix \\ Privatization Experiences}

\section{France}

One of the earliest converts to privatization was the French right-wing movement, led by jacques Chirac, Raymond Barre and Valery Giscard Esting. When they were returned to power in 1986 they were determined to embark on a programme of privatization in the teeth of reluctance by the socialist President, Francois Mitterand. Their constitution and the framework of the state owned industrial sector allowed them to enact a single sweeping law enabling 65 privatizations to take place. A supporting law provided for an independent commission to set a minimum price for the sale of any state asset, and gave the Minister of Finance the power to limit any single holding to five per cent of a privatized company's shares, and foreigners to a combined total of 20 percent. It sanctioned special shares and preferential treatment for both employees and small investors. This gave the executive arm of government the immediate power to aim at any or all of privatization's Six Goals.

It so happened that France had a series of state industries that were already treading on a commercial basis in conditions of fairly free competition without raising any particular environmental, security or consumer issues. So within a year clutch banks, a television channel, a telephone maker, an electricity company and the industrial group Saint Gobain all passed through the privatization process in a sequence which corresponded to the early stages in Britain. The sequence has been halted since the election of the socialist Michel Rocard as Prime Minister, but the evidence of opinion polls suggests that privatization has established a widespread popularity in France.

\section{Italy}

The management of Italy's massive state holding companies, IRI and ENI, have taken seemingly autonomous decisions to divest themselves of at least part of their wide-ranging collections of industrial investments. IRI is largely interested in banking and the heavy industries-iron, steel, shipyards and the like whilst ENI is more concerned with oil and gas. The lead of ENI has said that he wants to obtain stock market listings for all subsidiaries that are capable of reaching the appropriate status.

\section{Portugal}

Portugal began a privatization programme in 1988, pending the revision of the constitution to allow sales of more than 49 percent of the equity in state-run enterprises, which is not complete and allows $100 \%$ sales. The state banking, brewing, insurance and petro-chemical companies are in the first tranche. Small shareholders and employees are being given preference for up to 20 percent of the shares in each case, while individual institutions and total foreign holdings are being limited to 10 percent each.

\section{Spain}

Spain is privatizing parts of its state oil company, INH, despite the socialist flavour of the central government. It also has a list of planned private sales, covering banking, high technology, construction and bus manufacture. Iberia, the state airline, is to be sold after it has been profitable for at least three years. It is also breaking the state television monopoly by creating a new independent regulatory authority to supervise three new privately-run channels. 


\section{Turkey}

The Ozal Government in Turkey has committed itself to rolling back the very sizeable state industrial portfolio after an extensive study, culminating in the preparation of the Turkish Privatization Master Plan. It has set up the Public Participation Fund Administration to organize the process and act as a Centre for research into the subject. Cement, aircraft handling, tourism and telecommunications were early candidates.

\section{Egypt}

The Egyptian Government has sold several hotels and the Ministry for Tourism and Civil Aviation is lobbying to be allowed to sell Egypt Air.

\section{United States}

The U.S. has historically been reluctant to take many activities under direct public control, at either national or state level. However, a large number of local services have been contracted out to private suppliers, notably prisons, refuse collection, road repair, school catering, care for the elderly and public transport. However, there was very little actually to sell or float on the stock market. Nevertheless, the 1987 Budget included provision for the privatization of Conrail and Amtrak, the railroads, the Naval Petroleum Reserve and power Marketing Administration, which handles a modest part of U.S. electricity requirements. Conrail was the first to be sold. The shares went to a decent premium when they were floated, without laying the government open to charges of engineering a "giveaway". That was encouraging news for foreign governments considering the privatization of their own rail system.

\section{Canada}

The Canadian Government was similarly sympathetic to the idea of privatization, and had more stocks of privatizable assets to draw on. Air Canada, Canadair, Canada Development Corporation, Canadian Arsenals, CNR Route, Fecheries Canada, PetroCanada, De Havilland Aircraft, Teleglobe and Nanisivik Mines have either been sold or are being prepared for privatization. Most of the transactions so far have been trade sales rather than public floatations. The Canadian provincial governments have been just as active, pursuing contracting-out schemes and selling mines and oil companies. These include the restructuring of Alberta Government Telephones and the privatization of the British Columbia Transit Authority and the Halifax Sewage Treatment Facility.

\section{Mexico}

South of the U.S. in Mexico, the left-wing Partido Revolucionario Institutional has taken the drastic step of liquidating more than 50 state owned enterprises. Others have been transferred from the central to state governments, and several have been sold to the private sector, including banks, tourist business, mines and textile manufacturing operations.

\section{Jamaica}

in Jamaica the Government has undertaken the development of a privatization prograwme, and has al ready priratized the Caribbean Cement Company, National Commercial Bank and 13 percent of Tele communications of Jamaica. The rest of National Commercial way be sold, along with wore of the telecoms company. Methods are being examined to see if the electricity and oil industries can be privatized. 


\section{Chile}

In South America, the Chilean government has a privatization programme which predates Britain's by six years. In the early 1970's Chile's capital market was effectively given birth by the decision to privatize the state pension funds. The electricity industry has been privatized, along with banks, telecommunications, steel, pharmaceuticals, explosives and the fertiliser industry.

\section{Brazil}

In 1988 the Brazilian Government passed laws to initiate and regulate the privatization process. Rail-ways, petrochemical operations, computer activities, fuel distribution and steel mills are on the list for sale, despite considerable political opposition. The Government has commissioned studies and carried out evaluations for the privatization of COFA VI, a steel company, and VASP, an airline.

\section{Japan}

Despite a lack of any strong ideological commitment, the ruling Japanese party has nevertheless found privatization attractive, not least because it helps to keep the Tokyo Stock Exchange the biggest in terms of total market capitalization. It is also a means of emphasising Japan's economic power, the floatation of Nippon Telephone \& Telegraphy in 1986 and 1987 dwarfed British Telecom. Airlines, railways, and the state tobacco monopoly are all due for similar treatment, even though they are not quite in the same league in terms of size. Contracting-out has also been popular, particularly in respect of cleaning, refuse collection and security services.

\section{Malaysia}

Further south, in Malaysia, the Government has undertaken the privatization of the Kelang Container Terminal, the Kepong interchange, the Social Welfare lotteries Board, the Postal Services Department, Government Medical Stores, Kelang Port Authority, Sabah Gas Industries and the Jengka Triangle timber complex.

\section{Singapore}

At the end of the peninsular, Singapore Government is planning to privatize the mass transit railway system and the gas and electricity industries. Also under consideration are the Civil Aviation Authority of Singapore and the Port Authority.

\section{New Zealand}

The socialist government in New Zealand has produced its own variation on the privatization theme. It has turned state activities in land, coal and telecommunications into corporations capable of raising capital privately through what it calls equity bonds in effect, non-voting share-so that the state retains complete control. But there have been some private sales, notably of NZ Steel, Petrocorp and Air New Zealand. The electricity and telecommunications industries are also being examined to see if they should be privatized.

\section{Kenya}

Third-world privatizations have been proceeding vigorously, largely prompted by international agencies eager to see reductions in these countries' budget deficits. In 1988 Kenya sold part of the equity in its Commercial Bank. The other nationalized bank, National Bank of Kenya, is due to be privatized. 


\section{South Africa}

The South African Government formally launched a privatization programme in 1988. South African Transport Services is being divided into passenger, freight, airlines and pipelines as a prelude to privatization. The state aluminium and fertiliser companies are to be sold and studies have been taking place in the electricity industry.

Despite this impressively wide range of privatization activity across the world, it is clear that virtually every transaction has been to draw on the experience gained in the UK, Britain has been fortunate in that it has a highly developed capital market accompanied by a sophisticated financial service sector. As privatization has broken new ground in terms of size and the necessary marketing techniques, the advistory community has acquired a unique experience in coping with these new challenges.

This perhaps points up the most important lesson of the experience so far that it is vitally important to prepare as thoroughly as possible before embarking on individual privatization transactions, and that preparation must include rearing or importing the appropriate standard of advice.

\section{United Kingdom}

United Kingdom Privatized companies include: Amersham, Association, British Ports, BAA, British Aerospace, British Airways, British Gas, British Petroleum, British Steel, British Telecom, Cable \& Wireless, Enterprise Oil and Rolls-Royce. The major privatizations of the mid-1980's British Telecom and British Gas were primarily directed towards raising revenue for the State and widening share owner-ship. The recent move towards the privatization of the UK water and electricity authorities has placed emphasis on the achievement of greater efficiency based on the disciplines of the private sector and the introduction of competition. 


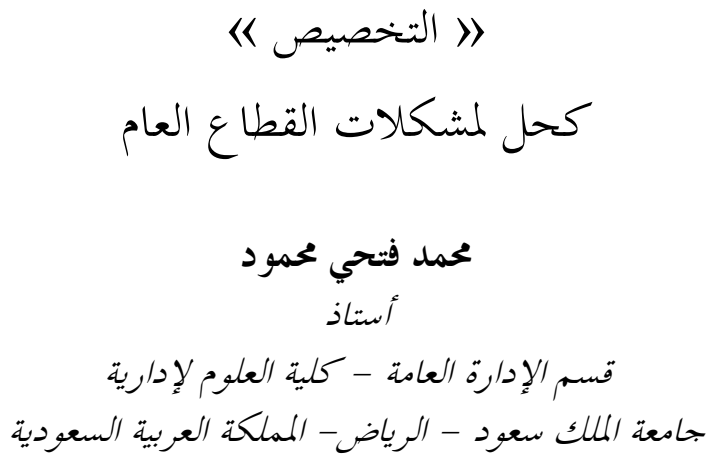

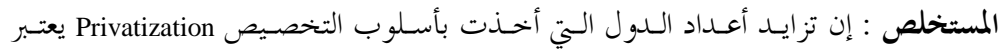

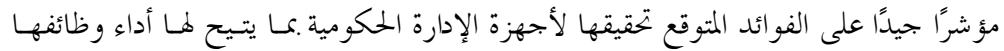

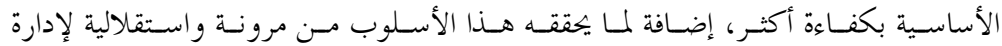

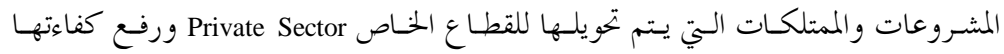
وتخسين مستوى أدائها.

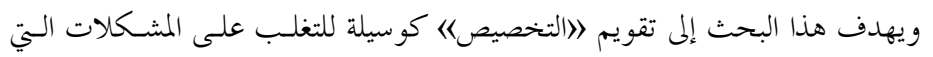

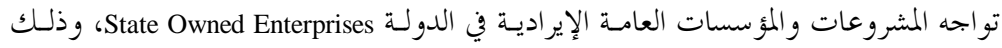

- العوامل التي تؤدي إلى ضعف أداء هذه المؤسسات.

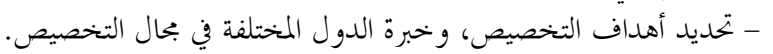

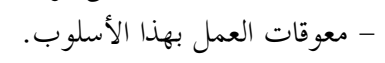
- أثر المنافسة على المنشآت التي تتحول للقطاع الخاص.

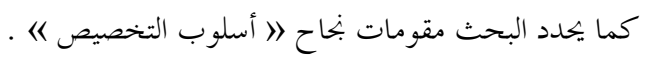

